\title{
UPAYA PEMULIHAN INDUSTRI PARIWISATA DALAM SITUASI PANDEMI COVID -19
}

\author{
Desy Tri Anggarini \\ Universitas BSI Jakarta, desy.dra@bsi.ac.id
}

\begin{abstract}
ABSTRAK
Pandemi COVID-19, Indonesia mengalami keterpurukan hampir seluruh industri kecuali bidang kesehatan, farmasi kegiatan sosial, informasi dan komunikasi, pengadaan air bersih, pengelolaan sampah, serta limbah daur ulang. Sektor yang paling terdampak yaitu transportasi, travel, gudang dan sektor penyediaan akomodasi serta makan. Kemudian sektor yang lain adalah sektor pariwisata di Indonesia, sekitar 11,83\% pekerja Indonesia berada sektor Industri pariwisata. Tujuan dari penelitian ini adalah meninjau dampak dari Covid -19 yang mengakibatkan turunnya sektor industri pariwisata di Indonesia dan juga merespon dari kebijakan Pemerintah agar penanganan dampak Covid -19 terhadap sektor pariwisata dapat dilakukan dengan baik dan pariwisata kembali normal dengan prosedural kesehatan. Penelitian ini menggunakan metode deskriptif kualitatif dan data untuk penelitian ini berdasarkan pada studi kepustakaan berupa buku, literature, jurnal, artikel mengenai industri pariwisata, serta cara pemulihannya pada era pandemi. Kunjungan wisatawan mancanegara berdasarkan data dari Kementrian Pariwisata dan Ekonomi Kreatif, ke Indonesia bulan Agustus 2020 mengalami penurunan sebesar -89,22\% dibandingkan Agustus 2019. Upaya pemulihan sektor pariwisata ada tiga strategi yang diterapkan untuk mempercepat pemulihan pariwisata adalah Inovasi adalah hal utama dan harus ada perubahan mendasar saat ini. Inovasi, Adaptasi beradaptasi dengan kondisi pandemi yaitu meningkatkan penerapan 'CHSE' alias Cleanliness (Kebersihan), Health (Kesehatan), Safety (Keamanan), dan Environment (Ramah lingkungan) dan Kolaborasi.
\end{abstract}

Kata kunci : Industri Pariwisata, Covid-19, Pemulihan Pariwisata

\begin{abstract}
ABSTRAK
The COVID-19 pandemic, Indonesia experienced a downturn in almost all industries except for health, pharmacy, social activities, information and communication, provision of clean water, waste management, and waste recycling. The sectors most affected are transportation, travel, warehouses and the accommodation and food provision sector. Then the other sector is the tourism sector in Indonesia, around 11.83\% of Indonesian workers are in the tourism industry sector. The purpose of this study is to review the impact of Covid -19 which resulted in a decline in the tourism industry sector in Indonesia and also to respond to Government policies so that handling of the impact of Covid -19 on the tourism sector can be done properly and tourism returns to normal with health procedures. This study uses a qualitative descriptive method and the data for this research is based on literature studies in the form of books, literature, journals, articles about the tourism industry, and how to recover it in the pandemic era. Foreign tourist visits based on data from the Ministry of Tourism and Creative Economy, to Indonesia in August 2020 experienced a decline of $-89.22 \%$ compared to August 2019. There are three strategies implemented to restore tourism to accelerate tourism recovery. Innovation is the main thing and must exist. fundamental change at this time. Innovation, Adaptation to adapt to pandemic conditions, by continuously increasing the application of 'CHSE' Cleanliness, Health, Safety, and Environment and Collaboration.
\end{abstract}

Keywords: Tourism Industry, Covid-19, Tourism Recovery

ISSN: 2355-6587, e-ISSN: 2528-2220

http://ejournal.bsi.ac.id/ejurnal/index.php/jp 


\section{PENDAHULUAN}

Risiko Ekonomi dalam pandemi COVID-19 telah mengakibatkan resesi diseluruh Negara, termasuk Indonesia. Adanya perlambatan pertumbuhan ekonomi di triwulan I 2020 dan pertumbuhan yang negatif pada triwulan II dan III tahun 2020. Dampak pandemik terhadap perekonomian pada sektor informal karena mereka memiliki pendapatan rendah, juga tabungan yang rendah, cenderung tidak memiliki proteksi asuransi atau tabungan dan status tenaga kontrak (ILO, 2020).

Beberapa sektor yang mengalami keterpurukan di masa pandemic COVID 19 adalah: (1) Sektor akomodasi dan penyediaan makan minum. Hal ini mengalami penurunan output karena terjadi penurunan jumlah wisatawan lokal dan mancanegara, banyak kejadian pembatalan kegiatan seperti pertemuan, meeting/ rapat, konferensi di hotel oleh instansi pemerintah maupun swasta; (2) Sektor Industri Pengolahan yaitu Industri Makanan Minuman mengalami penurunan output akibat menurunnya permintaan luar negeri, terlihat dari data ekspor komoditas makanan dan minuman; (3) Transportasi kereta dan udara yang mengalami penurunan dikarenakan jumlah penumpang yang sedikit juga akibat adanya pembatalan perjalanan kereta api dan pesawat karena kekhawatiran penyebaran COVID-19 (Tusianti, 2020).

Situasi pandemi Covid-19 mengakibatkan terganggunya pada rantai pasok global, dalam negeri, pasar keuangan, permintaan konsumen serta dampak negatif di sektor utama salah satunya perjalanan dan pariwisata. Dampak dari pandemi Covid-19 sangat berpengaruh diseluruh rantai nilai pariwisata, perusahaan kecil dan menengah disektor pariwisata juga ekonomi kreatif (Sugihamretha, 2020).

Badan Pusat Statistik mencatat kunjungan wisatawan mancanegara (wisman) yang masuk ke Indonesia awal tahun 2020 mengalami penurunan yaitu 7,62 persen bila dibandingkan jumlah kunjungan wisatawan mancanegara bulan Desember 2019 sebanyak 1,37 juta. Hal ini terjadi karena penurunan jumlah kunjungan ini disebabkan karena merebaknya Covid-19 yang terjadi di akhir Januari 2020.

Sektor yang terkena dampak diantaranya akomodasi dan makan minum, industry pengolahan (terutama tekstil) dan perdagangan. Hal ini tersebut masih banyaknya yang bekerja dengan status pekerja informal. Pada saat pandemi, banyak pengusaha yang mengalami kebangkrutan akibat keterbatasan keuangan (ILO, 2020). Keterbatasan modal tersebut karena adanya ketimpangan akses terhadap aset (Kende-Robb, 2019).

Pada industri pariwisata terlihat pada penurunan yang besar dari kedatangan kunjungan wisatawan mancanegara juga pembatalan penerbangan tiket pesawat, hotel serta penurunan pemesanan. Hal ini juga terjadi penurunan karena perlambatan perjalanan domestik, terutama wisatawan domestik, keengganan masyarakat untuk melakukan perjalanan, dikhawatir penyebaran dampak Covid-19 di daerah wisata. Hal ini juga terjadi pada penurunan bisnis pariwisata dan perjalanan berdampak pada usaha UMKM, pekerja informal dan lapangan kerja semakin turun. Perlu kita ketahui bahwa selama ini pariwisata adalah sektor padat karya yang menyerap tenaga kerja lebih dari 13 juta pekerja, dampak turunan atau multiplier effect yang mengikuti termasuk industri turunan yang terbentuk dibawahnya juga mengalami imbas dari pandemik COVID 19 di sektor pariwisata (Sugihamretha, 2020).

Pandemi COVID-19, Indonesia mengalami keterpurukan hampir seluruh industri kecuali bidang kesehatan, farmasi kegiatan sosial, informasi dan komunikasi, pengadaan air bersih, pengelolaan sampah, serta limbah daur ulang. Sektor yang paling terdampak yaitu transportasi, travel, gudang dan sektor penyediaan akomodasi serta makanan juga sektor yang lain adalah sektor pariwisata di Indonesia, berdasarkan Sakernas 2019, sekitar $11,83 \%$ pekerja Indonesia berada sektor Industri pariwisata. Sementara, kontribusi pariwisata terhadap PDB sekitar $4 \%$ per tahun (Tusianti, 2020). 
Pandemi Covid-19 berdampak seluruh negara G20 mengalami resesi. Sebagian G20 diprediksi mengalami pertumbuhan ekonomi negatif, hanya 3 negara G20 yang diprediksi masih menunjukkan pertumbuhan ekonomi positif ditahun 2020 yaitu Indonesia, India, dan Cina. Indonesia diprediksi mengalami pertumbuhan PDB riil pada tahun 2020 masih berada diangka 1 persen, sementara sebelum Covid-19 prediksi pertumbuhan PDB Indonesia yaitu 5,1 persen dan untuk sektor industri pariwisata juga menurun akibat terhambatnya proses mobilitas antarnegara (Sugihamretha, 2020).

Penurunan wisatawan asing ke Indonesia berpengaruh terhadap penerimaan devisa dari sektor pariwisata. Hal ini mengakibatkan lebih dari USD1,3 miliar penerimaan devisa dari pariwisata. Negara Tiongkok adalah wisatawan mancanegara terbanyak kedua di Indonesia.

Berdasar data Survei Tenaga Kerja Nasional (Sakernas), tenaga yang terserap di industri pariwisata terus meningkat dari jumlah tenaga kerja, juga industri pariwisata terhadap penyerapan tenaga kerja nasional juga terus meningkat. Hal ini menunjukkan industri pariwisata dapat menjadi salah satu alternatif untuk mengurangi tingkat pengangguran.

Hal tersebut sangat penting karena industri pariwisata menyerap tenaga kerja dan memiliki peranan dalam perekonomian.

Tujuan dari penelitian ini adalah meninjau dampak dari Covid -19 yang mengakibatkan turunnya sektor industri pariwisata di Indonesia dan juga merespon dari kebijakan Pemerintah agar penanganan dampak Covid -19 terhadap sektor pariwisata dapat dilakukan dengan baik dan dan pariwisata kembali normal dengan prosedural kesehatan.

\section{KAJIAN LITERATUR}

UU No. 10 Tahun 2009 mengenai definisi pariwisata adalah industri pariwisata merupakan kumpulan usaha saling terkait dalam rangka menghasilkan barang dan/ atau jasa untuk pemenuhan kebutuhan wisatawan dalam penyelenggaraan pariwisata, dan usaha pariwisata adalah usaha dalam menyediakan barang dan/ atau jasa bagi pemenuhan kebutuhan wisatawan serta penyelenggara pariwisata.

Industri pariwisata adalah salah satu industri yang memiliki keterkaitan dengan sektor lain, karena pariwisata dikatakan sebagai gabungan fenomena dan hubungan timbal balik yaitu adanya interaksi dengan wisatawan, supplier bisnis, pemerintah dan tujuan wisata serta masyarakat daerah wisata

Sinergi ekonomi kreatif dan pariwisata akan menghasilkan permulihan ekonomi dan berkembangnya pariwisata yang positif, yang diharapkan terjadi pengembangan pemberdayaan masyarakat (komunitas setempat) melalui ekonomi kreatif sangat membawa hal positif, inilah merupakan salah satu model pembangunan pariwisata ke depan. Pemberdayaan bukan hanya dalam pengembangan potensi ekonomi masyarakat yang sedang terpuruk karena pandemi, namun juga upaya peningkatan percaya diri, harga diri, dan harkat, martabat serta terpeliharanya tatanan nilai kultural dan budaya setempat (Wulandari, 2014).

Fasililtas pariwisata, berdasarkan PP No. 50 tahun 2011 tentang RIPPARNAS, fasilitas tersebut terbagi yaitu: (1) akomodasi; (2) rumah makan; (3) informasi dan pelayanan wisata; (4) pelayanan keimigrasian; (5) pusat informasi pariwisata (tourism information center); (6) e-tourism kiosk; (7) polisi dan satgas wisata; (8) toko cinderamata (souvenir shops); (9) penunjuk arah wisata; (10) landscaping.

Sektor industri pariwisata sekarang ini harus beradaptasi dengan metode yaitu media promosi dan pemasaran online. (Atiko, G., Sudrajat, R. H., \& Nasionalita, 2016) telah melakukan sebuah penelitian yang mengkaji penggunaan media sosial (online) seperti Instagram untuk mempromosikan tujuan wisata di Indonesia kemudian disertai visualisasi untuk tujuan mendapatkan target wisatawan yang lebih luas. 
Penelitian lain mengenai Agen Travel Online mempromosikan untuk berperan serta dalam pilihan media promosi perjalanan wisata. Semakin banyaknya agen online tersebut mengindikasikan bahwa wisatawan domestik maupun mancanegara lebih cenderung memilih online untuk keperluan perjalanan wisata (Pitanatri, P. D., \& Pitana, 2016).

Sumber daya manusia dan pekerja dalam industri pariwisata merupakan penunjang pariwisata yang memegang peranan utama dan strategis, secara keseluruhan kualitas pelayanan pariwisata akan baik jika sumber daya manusia dan pekerja dalam industri pariwisata yang dimiliki juga memiliki kualitas dan kompetensi yang diperlukan (Winarno, 2010).

(Warmayana, 2018) melakukan penelitiannya dengan menemukan bahwa peran digital marketing pada situasi saat ini sangat positif dalam menarik minat wisata khususnya terhadap generasi $\mathrm{Y}$ dan $\mathrm{Z}$. Promosi serta pemasaran secara online juga bergantung pada sumber daya manusia yang berkompeten di bidangnya hal tersebut berdasarkan pada lima dimensi kualitas pelayanan yang disampaikan oleh (Tjiptono, 2015).

Pergeseran metode pemasaran offline ke online kemudian target wisatawan saat ini adalah usia muda, maka sudah seharusnya jika promosi, juga pemasaran melalui media internet dan media sosial. Promosi adalah kunci untuk meningkatkan dan memulihkan kunjungan wisatawan (Puspawati, D. P. H., \& Ristanto, 2018).

\section{METODE PENELITIAN}

Penelitian Upaya Pemulihan Industri Pariwisata Dalam Situasi Pandemi Covid -19 ini menggunakan metode analisis statistik deskriptif kualitatif (Arikunto, 2010) untuk memahami fenomena Pandemi Covid 19 yang mengancam keterpurukan ekonomi salah satunya sektor industri pariwisata di Indonesia.

Data untuk penelitian ini berdasarkan pada studi kepustakaan berupa buku, literature, jurnal, artikel mengenai industri pariwisata, serta cara pemulihannya pada era pandemi.(Sugiyono, 2010)

Penelitian ini menggunakan data sekunder yaitu data yang dijadikan sebagai bahan pendukung dari penulisan penelitian dalam arti lain sebagai sumber informasi yang tidak secara langsung mempunyai wewenang dan pemberi informasi. Dalam penelitian ini data sekunder diambil dari Badan Pusat Statistik dan data dari Kementrian Pariwisata dan Ekonomi Kreatif (Arikunto, 2010).

\section{PEMBAHASAN}

Badan Pusat Statistik mencatat kunjungan wisatawan mancanegara (wisman) yang masuk ke Indonesia awal tahun 2020 mengalami penurunan. Pada bulan Januari 2020, tercatat kunjungan wisman mencapai 1,27 juta kunjungan. Angka ini menurun 7,62 persen bila dibandingkan jumlah kunjungan wisatawan mancanegara bulan Desember 2019 sebanyak 1,37 juta. Hal ini terjadi karena penurunan jumlah kunjungan ini disebabkan karena merebaknya Covid-19 yang terjadi di akhir Januari 2020.

Penurunan kunjungan wisatawan asing ketanah air juga terlihat dari data wisatawan asing yang datang melalui udara (bandara), jika dibandingkan dengan kunjungan pada bulan Desember 2019, jumlah kunjungan wisatawan asing ke Indonesia melalui pintu masuk bandara pada bulan Januari 2020 mengalami penurunan 5,01 persen.

Kunjungan wisatawan mancanegara berdasarkan data dari Kementrian Pariwisata dan Ekonomi Kreatif, ke Indonesia melalui keseluruh pintu masuk bulan Agustus 2020 berjumlah 164.970 kunjungan artinya mengalami penurunan sebesar -89,22\% dibandingkan Agustus 2019 yang berjumlah 1.530.268 kunjungan wisatawan mancanegara, terlihat dalam Gambar 1.

Dalam Gambar 1 kunjungan wisatawan mancanegara ada tiga pintu besar dari 26 pintu masuk utama pada bulan Agustus 2020 dibandingkan bulan Agustus 2019, yaitu: 
Berdasarkan kebangsaan, jumlah kunjungan wisatawan mancanegara pada bulan Agustus 2020 di seluruh pintu masuk jumlah pengunjung tertinggi, yaitu: Timor Leste sebesar 88.408 kunjungan, Malaysia sebesar 58.291 kunjungan, Tiongkok sebesar 3.655 kunjungan, Amerika Serikat sebesar 1.768 kunjungan, dan Belanda sebesar 1.367 kunjungan wisatawan mancanegara. Jumlah kunjungan wisatawan mancanegara pada bulan Agustus 2019 adalah 1.530,27.

PERKEMBANGAN WISMAN BULAN AGUSTUS 2020

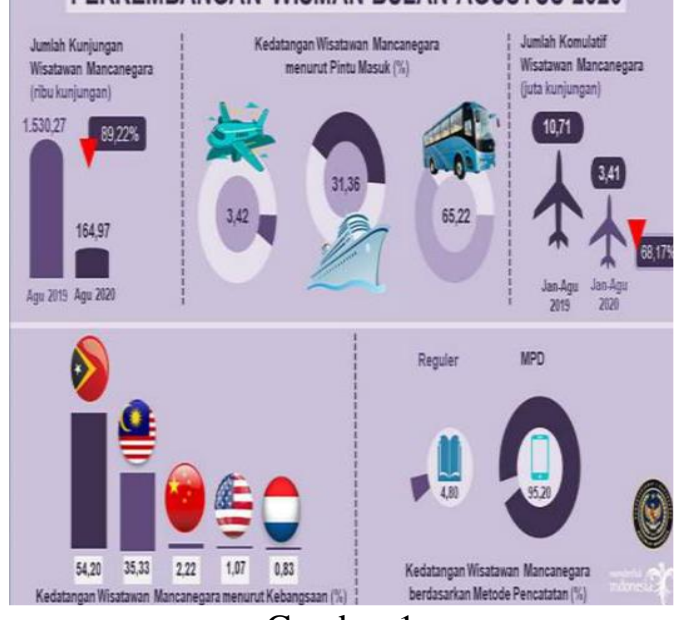

Gambar 1

Perkembangan Wisatawan Mancanegara Bulan Agustus 2020

Sumber : Kementrian Pariwisata dan Ekonomi Keatif (2020)

Tabel 1.

\section{Perkembangan Wisman 2020}

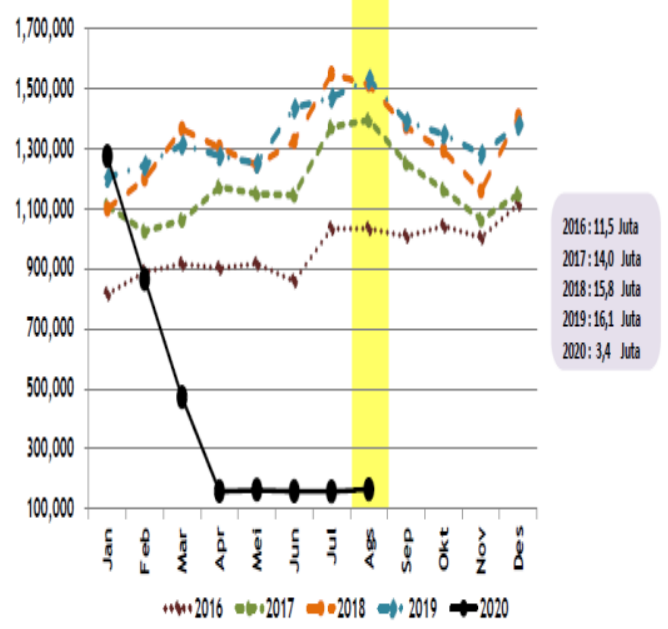

Sumber : BPS RI (2020)
Berikut ini adalah perkembangan wisatawan mancanegara yang masuk ke Indonesia dari tahun ke tahun dari Tabel 1. Terlihat bahwa peningkatan yang cukup signifikan dari tahun 2016 sampai dengan tahun 2019. Tahun 2016 ada 11.5 juta wisatawan mancanegara yang masuk ke Indonesia, kemudian tahun 2017 meningkat menjadi 14.0 juta wisatawan mancanegara, tahun 2018 kunjungan wisatawan mancanegara meningkat menjadi 15,8 juta, dan tahun 2019 jumlah kunjungan wisatawan menjadi 16,1 juta jiwa. Hal ini karena perkembangan kondisi pariwisata nasional merupakan dampak dari peningkatan perekonomian Indonesia yang tinggi. Pertumbuhan perekonomi yang meningkat disertai daya beli masyarakat juga didukung dengan keadaan keamanan yang relatif kondusif, hal tersebut berdampak meningkatnya jumlah kunjungan wisatawan, terutama wisatawan domestik, melakukan perjalanan wisata di Indonesia.

Berikut disajikan gambaran umum mengenai karakteristik pada awal pandemi Covid -19 di Indonesia, pada awal Januari 2020 terjadi penurunan yang cukup signifikan sampai dengan bulan April terjadi lockdown di Indonesia maupun di negara lainnya. Mengakibatkan beberapa penerbangan internasional di negara lain tutup, sehinga tidak ada peningkatan jumlah wisatawan mancanegara di bulan April 2020 sampai dengan Agustus 2020 yaitu 3,4 juta wisatawan mancanegara.

Tabel 2

Perkembangan Wisman melalui Bandara

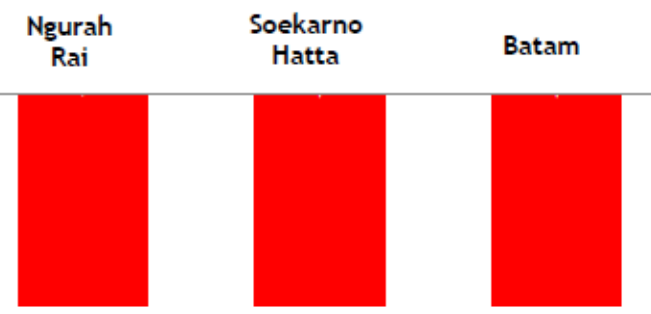

Sumber : BPS RI (2020)

Tabel 2 terlihat penurunan dikarenakan seluruh pintu masuk utama seperti bandara Ngurah Rai mengalami penurunan jumlah pengunjung sebesar $100 \%$, kemudian bandara Soekarno Hatta

ISSN: 2355-6587, e-ISSN: 2528-2220 
mengalami penurunan jumlah pengunjung sebesar -98,22\%; dan bandara Batam mengalami penurunan jumlah pengunjung sebesar $-99,92 \%$. Sehingga terjadi penurunan wisatawan domestik dan wisatawan mancanegara yang masuk ke tempat wisata seperti Bali, Jakarta dan Batam.

Tabel 3

Perkembangan Wisatawan Masuk melalui bandara Ngurah Rai dan Soekarno Hatta

\begin{tabular}{|c|c|c|}
\hline \multicolumn{3}{|c|}{2020} \\
\hline \multirow[t]{2}{*}{ BULAN } & $\begin{array}{l}\text { Ngurah Rai, Ball } \\
\text { (U) }\end{array}$ & $\begin{array}{l}\text { Soekarno-Hatta, } \\
\text { Banten (U) }\end{array}$ \\
\hline & (1) & (2) \\
\hline \multicolumn{3}{|l|}{ JANUARI } \\
\hline 2020 & 526,823 & 173,453 \\
\hline 2019 & 451,708 & 174,963 \\
\hline Pertumbuhan (\%) & 16.63 & -0.86 \\
\hline \multicolumn{3}{|l|}{ FEBRUARI } \\
\hline 2020 & 358,254 & 131,032 \\
\hline 2019 & 436,266 & 196,183 \\
\hline Pertumbuhan (\%) & -17.88 & -33.21 \\
\hline \multicolumn{3}{|l|}{ MARET } \\
\hline 2020 & 155,851 & 52,631 \\
\hline 2019 & 441,707 & 214,161 \\
\hline Pertumbuhan (\%) & -64.72 & -75.42 \\
\hline \multicolumn{3}{|l|}{ APRIL } \\
\hline 2020 & 273 & 417 \\
\hline 2019 & 476,104 & 196,977 \\
\hline Pertumbuhan (\%) & -99.94 & -99.79 \\
\hline \multicolumn{3}{|l|}{ MEI } \\
\hline 2020 & 34 & 395 \\
\hline 2019 & 483,928 & 156,654 \\
\hline Pertumbuhan (\%) & -99.99 & -99.75 \\
\hline \multicolumn{3}{|l|}{ JUNI } \\
\hline 2020 & 10 & 909 \\
\hline 2019 & 549,483 & 190,031 \\
\hline Pertumbuhan (\%) & -100.00 & -99.52 \\
\hline \multicolumn{3}{|l|}{ JULI } \\
\hline 2020 & 16 & 3,119 \\
\hline 2019 & 604,310 & 267,143 \\
\hline Pertumbuhan (\%) & -100.00 & -98.83 \\
\hline \multicolumn{3}{|l|}{ Agustus } \\
\hline 2020 & 12 & 4,469 \\
\hline 2019 & 602,457 & 251,596 \\
\hline Pertumbuhan (\%) & -100.00 & -98.22 \\
\hline $\begin{array}{c}\text { Pertumbuhan } \\
\text { Agustus } 2020 \text { thd } \\
\text { Juli } 2020 \text { (\%) }\end{array}$ & -25.00 & 43.28 \\
\hline \multicolumn{3}{|l|}{ JAN-AGU } \\
\hline 2020 & $1,041,273$ & 366,425 \\
\hline 2019 & $4,045,963$ & $1,647,708$ \\
\hline Imbuha & -74.26 & -77.76 \\
\hline
\end{tabular}

Sumber : BPS RI (2020)

Berikut ini adalah jumlah wisatawan yang masuk melalui Bandara Ngurah Rai Bali dan Bandara Soekarno Hatta Banten, pada awal Januari 2019 ada 526.923 jumlah wisatawan yang masuk melalui Bandara Ngurah Rai dana Januari 2020426.923 jumlah wisatawan yang masuk, hal ini masih positif pertumbuhannya sekitar $16.63 \%$. Namun berbeda dengan Bandara Soekarno Hatta Banten terlihat penurunan di awal Januari
2020 dengan pertumbuhan yang negatif $0.86 \%$.

Kemudian di Bulan Maret 2020 terjadi penurunan jumlah wisatawan sebesar - $64.72 \%$ di Bandara Ngurai Rai Bali, hal ini pada bulan tersebut merupakan awal dari pandemi yang mengakibatkan beberapa negara melakukan lockdown juga membatasi penerbangan internasional. Bandara Soekarno Hatta bulan maret 2019 jumlah kunjungan 214.161 turun menjadi 52.631 hal ini menjadikan penurunan yang signifikan yaitu $-75.42 \%$.

Pada bulan Agustus 2020 terjadi penurunan - $100 \%$ di Bandara Ngurah Rai Bali, penurunan yang sangat signifikan dari Agustus 2019 yaitu 602.457 menjadi 12 di bulan Agustus 2020, hal ini juga terjadi di Bandara Soekarno Hatta minus $98.22 \%$. Dari pertumbuhan negatif ini, sektor pariwisata yang mengandalkan wisatawan mancanegara tentunya membawa imbas bagi seluruh industri pariwisata di Indonesia, termasuk juga sektor formal, informal, UMKM di daerah pariwisata.

Upaya pemulihan sektor pariwisata oleh Menteri Pariwisata dan Ekonomi Kreatif Sandiaga Uno ada tiga strategi yang diterapkan untuk mempercepat pemulihan pariwisata. Strategi tersebut disampaikan dalam rapat utama sebagai menteri pada saat serah terima jabatan.

Inovasi adalah hal utama dan harus ada perubahan mendasar saat ini, pemerintah mengupayakan destinasi prioritas. Inovasi harus dilakukan dalam segi infrastruktur, budaya, kuliner hingga fesyen dan semua hal yang berkaitan dengan pariwisata juga ekonomi kreatif

Adaptasi merupakan hal yang harus diterapkan karena semua pihak harus bisa beradaptasi dengan kondisi pandemi Covid-19, yaitu dengan terus meningkatkan penerapan ' $\mathrm{CHSE}$ ' alias Cleanliness (Kebersihan), Health (Kesehatan), Safety (Keamanan), dan Environment (Ramah lingkungan).

Kolaborasi adalah semua pihak harus bisa bekerjasama dan berkolaborasi dengan sektor pariwisata karena jutaan lapangan pekerjaan terdampak pada sektor 
pariwisata dan ekonomi kreatif, hal inilah yang harus kita perjuangkan agar lapangan pekerjaan terbuka luas, dan meningkatnya pendapatan masyarakat.

Strategi untuk meningkatkan sektor industri pariwisata dan ekonomi kreatif adalah dengan pemanfaatan Teknologi dan Informasi bagi Tenaga Kerja informal dan UMKM untuk dapat bertahan di tengah pandemi COVID-19.

Menurut LIPI (2020), langkah awal dalam upaya membangkitkan kembali UMKM membangkitkan pekerja informal dalam indutri pariwisata dalam jangka pendek adalah dengan menciptakan stimulus permintaan dan mendorong platform digital (online) untuk memperluas kemitraan, disamping upaya yaitu melalui kerjasama serta pemanfaatan inovasi dan teknologi yang menunjang perbaikan mutu dan daya saing produk, seperti pengolahan produk, kemasan serta sistem pemasaran dan lainnya.

Pelaku UMKM dan pekerja sektor informal di industri pariwisata memiliki kesempatan dalam meningkatkan usahanya melalui sistem perdagangan elektronik (online) dan melakukan kemitraan. Hal ini merupakan suatu peluang dalam meningkatnya transaksi online selama pandemi (Satgas COVID-19, 2020).

Hal ini diharapkan pekerja informal dan UMKM di sektor pariwisata dapat bertahan, selama pandemi serta perlu dilakukan dalam meningkatkan kelembagaan yaitu membangun jaringan atau tergabung sebuah kemitraan. Pemanfaatan teknologi sudah menjadi sebuah keharusan, peningkatan layanan onlinebagi UMKM dan sektor informal industri pariwisata sangat penting, untuk promosi, komunikasi, proses penjualan barang/jasa, seperti melalui marketplace dan website/aplikasi. (Tusianti, 2020).

Pemerintah juga melakukan upaya berbagai cara untuk menyelamatkan sektor UMKM sektor pariwisata di tengah pandemi Covid-19, salah satu diantaranya dengan pemberian bantuan, subsidi dan relaksasi pinjaman.

Hal tersebut dilakukan pemerintah agar pekerja informal dan UMKM dapat bertahan, dalam situasi kondisi pandemi
Covid-19 yang perlu dilakukan adalah meningkatkan kelembagaan juga pemanfaatan teknologi.

Adanya kebijakan sektor industri pariwisata.

1. Tersedianya dana APBN Kementerian Pariwisata dan Ekonomi Kreatif sebesar Rp 298,5 miliar

2. Pemerintah telah memberikan insentif kepada agent wisata, penerbangan dan juga insentif seperti promosi pariwisata, famili trip dan influencer.

3. Tersedianya potongan harga tiket domestik yang diberikan kepada wisatawan domestik rata-rata yaitu $51,44 \%$ untuk $25 \%$ dari kapasitas seat penerbangan satu perjalanan, meliputi: Diskon sebesar 30\% untuk kuota $25 \%$ seats di penerbangan ke 10 tujuan wisata. Berlaku selama 3 bulan yaitu Maret, April, dan Mei 2020. Kebijakan bersebut berlangsung selama 3 bulan. Diskon ini untuk tujuan penerbangan domestik dengan destinasi wisata yaitu Denpasar, Batam, Bintan, Manado, Yogyakarta, Labuan Bajo, Belitung, Lombok, Danau Toba Labuan Bajo, Belitung dan Malang.

4. Adanya Insentif usulan dari asosiasi bahwa untuk pajak hotel dan restoran yang ada 10 destinasi wisata tarifnya dinolkan.

5. Memberikan hibah kepada pemda akibat penurunan tarif pajak hotel dan restoran di daerah yaitu sebesar Rp3,3 triliun.

6. APBN terdapat Rp147 miliar di bidang pariwisata saat ini belum mampu digunakan oleh pemda. Rencananya akan dikonversi menjadi hibah ke daerah sehingga bisa meningkatkan perkembangan pariwisata daerah.

7. Upaya mendorong pergerakan wisatawan domestik dengan melakukan promosi wisata dalam domestik.

8. Mempromosikan event musik dan olahraga yang sudah ada di dalam negeri, juga dilakukan upaya untuk menarik potensi MICE dan event 
internasional

diselenggarakan

agar

di

(Sugihamretha, 2020)

Berbagai dampak karena wabah Covid-19, selain intervensi kebijakan yang telah dilakukan untuk meminimalisasi dampak Covid-19 di sektor pariwisata :

1. Hal yang utama adalah melindungi mata pencaharian pekerja di bidang pariwisata. Bantuan keuangan harus diberikan untuk melindungi pendapatan pekerja.

2. Adanya dukungan Fiskal, pemerintah memberikan keringanan kepada perusahaan juga usaha kecil dan menengah di sektor pariwisata sebagai stimulus untuk mencegah keterpurukan sektor wisata.

3. Tambahan likuiditas dan bantuan uang tunai yang terdampak wabah covid -19 di sektor pariwisata.

4. Beberapa alternatif bantuan dana sosial dampak covid-19 untuk 12 juta tenaga kerja di sektor industri pariwisata.

5. Adanya rancang bangun aplikasi sistem informasi pariwisata yang berbasis android terdapat sekumpulan data industri pariwisata juga menyediakan data SDM pariwisata, jenis jasa, daya tarik, dan sarana wisata yang tersebar di Indonesia.

6. Adanya harga diskon untuk pesawat juga diskon harga sewa untuk toko dan agen kargo.

7. Adanya beasiswa dan pelatihan di Politeknik Pariwisata untuk memperpanjang tenggat waktu dalam pembayaran pajak dan kewajiban.

8. Adanya sumber pendanaan untuk penanggulangan bencana di sektor pariwisata skema pendanaan jangka pendek, skema kredit modal kerja bagi UMKM, sektor informal, dan juga potongan pajak penghasilan perusahaan.

9. Adanya kelembagaan mitigasi bencana disektor pariwisata di tingkat pusat sampai ke daerah.

10. Adanya buku pedoman standard baku tata kelola tentang perencanaan, pelaksanaan, dan pengendalian dampak wabah/bencana di sektor pariwisata (Sugihamretha, 2020).

\section{PENUTUP}

Upaya pemulihan sektor pariwisata ada tiga strategi yang diterapkan untuk mempercepat pemulihan pariwisata adalah.

1. Inovasi adalah hal utama dan harus ada perubahan mendasar saat ini, pemerintah mengupayakan destinasi prioritas. Inovasi harus dilakukan dalam segi infrastruktur, budaya, kuliner hingga fesyen dan semua hal yang berkaitan dengan pariwisata juga ekonomi kreatif.

2. Adaptasi merupakan hal yang harus diterapkan karena semua pihak harus bisa beradaptasi dengan kondisi pandemi Covid-19, yaitu dengan terus meningkatkan penerapan 'CHSE' alias Cleanliness (Kebersihan), Health (Kesehatan), Safety (Keamanan), dan Environment (Ramah lingkungan).

3. Kolaborasi adalah semua pihak harus bisa bekerjasama dan berkolaborasi dengan sektor pariwisata karena jutaan lapangan pekerjaan terdampak pada sektor pariwisata dan ekonomi kreatif, hal inilah yang harus kita perjuangkan agar lapangan pekerjaan terbuka luas, dan meningkatnya pendapatan masyarakat.

Pandemi COVID-19 telah membuat terpuruk hampir seluruh sektor, salah satunya indutri Pariwisata di Indonesia Hal ini juga mengakibatkan pelaku UMKM indutri pariwisata dan pekerja informal menjadi pihak yang paling rentan.

Beberapa kendala dihadapi pelaku UMKM dan pekerja informal sektor pariwisata adalah disebabkan oleh karakteristik usaha UMKM dan pekerja informal yang rentan masih memiliki keterbatasan dalam teknologi dan skill yang mampu menjadikan solusi akibat pandemi Covid -19 .

Pemerintah telah melakukan upaya berbagai cara untuk menyelamatkan sektor UMKM di tengah pandemi Covid19, salah satu diantaranya dengan pemberian bantuan, subsidi dan relaksasi pinjaman. Hal tersebut dilakukan pemerintah agar pekerja informal dan UMK dapat bertahan, dalam situasi kondisi di tengah pandemic Covid-19 yang perlu 
dilakukan adalah meningkatkan kelembagaan juga pemanfaatan teknologi.

Namun sangat disayangkan pekerja informal dan UMKM di sektor indutri pariwisata masih belum memiliki akses teknologi informasi dan komunikasi. Selain beberapa pelaku UMKM belum siap menghadapi bisnis online.

Kebijakan sektor industri pariwisata dalam pemulihan sektor wisata agar industri pariwista tidak terpuruk dari dampak Covid-19 yang dilakukan oleh pemerintah antara lain, tersedianya dana APBN Kementerian Pariwisata dan Ekonomi Kreatif sebesar Rp 298,5 miliar. Pemerintah memberikan insentif kepada agent wisata dan penerbangan.

Tersedianya diskon tiket domestik yang diberikan oleh wisatawan domestik Berlaku selama 3 bulan yaitu Maret, April, dan Mei 2020. Diskon ini untuk tujuan penerbangan domestik dengan destinasi wisata yaitu Denpasar, Batam, Bintan, Manado, Yogyakarta, Labuan Bajo, Belitung, Lombok, Danau Toba Labuan Bajo, Belitung dan Malang. Insentif usulan dari asosiasi bahwa untuk pajak hotel dan restoran yang ada 10 destinasi wisata tarifnya dinolkan.

Memberikan hibah kepada pemda akibat penurunan tarif pajak hotel dan restoran. Upaya mendorong pergerakan wisatawan domestik dengan melakukan promosi wisata dalam domestik.

Hal yang utama adalah melindungi mata pencaharian pekerja di bidang pariwisata. Bantuan keuangan harus diberikan untuk melindungi pendapatan pekerja.

Adanya rancang bangun aplikasi sistem informasi pariwisata yang berbasis android terdapat sekumpulan data industri pariwisata juga menyediakan data SDM pariwisata, jenis jasa, daya tarik, dan sarana wisata yang tersebar diIndonesia.

Diberikannya harga diskon untuk pesawat juga diskon harga sewa untuk toko dan agen kargo

Beasiswa dan pelatihan di Politeknik Pariwisata untuk memperpanjang tenggat waktu dalam pembayaran pajak dan kewajiban.
Buku pedoman standard baku tata kelola tentang perencanaan, pelaksanaan, dan pengendalian dampak wabah/bencana di sektor pariwisata.

\section{REFERENSI}

Arikunto, S. (2010). Metode Peneltian. Rineka Cipta.

Atiko, G., Sudrajat, R. H., \& Nasionalita, K. (2016). Analisis Strategi Promosi Pariwisata Melalui Media Sosial Oleh Kementrian Pariwisata Ri (Studi Deskriptif Pada Akun Instagram @Indtravel). Jurnal Sosioteknologi, 15(3), 378-389.

ILO. (2020). ILO 2020. ILO. https://www.ilo.org/wcmsp5/groups/ public/---dgreports/-gender/documents/publication/wcms _744685.pdf. \%0A

Kende-Robb, C. (2019). To improve women's access to finance, stop asking them for collateral. World Economic Forum. fromhttps://www.weforum.org/agend a/2019/06/women-financeleastdeveloped-countries-collatera.

Pitanatri, P. D., \& Pitana, I. (2016). (2016). Digital Marketing in Tourism: The More Global,The More Personal. International TourismConference Promoting Cultural \& Heritage Tourism.Udayana University.

Puspawati, D. P. H., \& Ristanto, R. (2018). (2018). Strategi Promosi Digital Untuk Pengembangan Pariwisata Kota Magelang. Jendela Inovasi Daerah, 1(2), 1-20.

Satgas COVID-19. (2020). Sistem ecommerce jadi solusi bagi pelaku umkm di tengah pandemi COVID-19. Satgas COVID-19. (2020, April 28). https://covid19.go.id/p/berita/sistemecommerce-jadi-solusi-bagi-pelakuumkm-di-tengah-pandemiCOVID19h\%0A\%0A

Sugihamretha, I. D. G. (2020). Respon Kebijakan: Mitigasi Dampak Wabah Covid-19 Pada Sektor Pariwisata,. The Indonesian Journal of Development Planning, Volume $I V($ Kementerian Perencanaan 
Pembangunan Nasional/Bappenas Republik Indonesia).

Sugiyono. (2010). Metode Penelitian Pendidikan Pendekatan Kualitatif, Kuantitatif dan $R \quad \& \quad D$. Bandung :Alfabeta.

Tjiptono, F. (2015). Strategi Pemasaran. Andi Offset.

Tusianti, E. P. D. R. (2020). Buku Analisis Isu Terkini 2020. BPS RI 2020. https://www.bps.go.id/publication/20 20/12/15/9a3bc3a1f990e919a6e05ba $\mathrm{d} /$ analisis-isu-terkini-2020.html

Winarno. (2010). Pengembangan Soft Skill dan Hard Skill Dalam Meningkatkan Kualitas Pelayanan. Jurnal Cakrawala, 10(2), 147-156.

Wulandari, L. W. (2014). Pengembangan Pariwisata Ekonomi Kreatif Desa Wisata Berbasis Budaya Sebagai Niche Market Destination (Studi Kasus Pengembangan Desa Wisata di Kabupaten. Aplikasi Bisnis, 16(9), 2140-2167.

\section{BIODATA PENULIS}

Desy Tri Anggarini, SE.,MM. adalah Dosen Universitas BSI Jakarta, dengan latar pendidikan S1 Universitas Diponegoro Semarang, Fakultas Ekonomi dan S2 Universitas Trisakti Jakarta, Magister Managemen. 